\title{
The Impact of Sustainability Practices on Firm Financial Performance: Evidence from Malaysia
}

\author{
Christopher Jerry Thomas ${ }^{1}$, Jasman Tuyon ${ }^{1 *}$, \\ Hylmee Matahir ${ }^{1}$, and Samir Dixit ${ }^{2}$ \\ ${ }^{1}$ Faculty of Business and Management, Universiti Teknologi MARA \\ Sabah Branch, Kota Kinabalu Campus, Malaysia \\ ${ }^{2}$ Brand Finance Asia Pacific, Singapore
}

\begin{abstract}
In line with the United Nations (UN) sustainable development agenda, corporate sustainability is a critical driver for a corporation's long-term survival. Despite the noble ideas, sustainability practices remain neglected in theory, policy, and selectively practiced by Malaysian corporations, possibly due to unclear impacts. This study aimed to provide an empirical analysis on the impact of sustainability practices on firm performance in the context of Malaysia using both aggregate and disaggregated environmental, social and governance (ESG). The study sample consisted of 36 public listed firms in Malaysia that have been consistently reporting ESG scores from 2015 to 2019. Static panel regression was used to analyse the data in annual frequency. In aggregate level, the results indicated a positive relationship between sustainability (ESG) and firm financial performance such as, return on assets (ROA), return on equity (ROE) and Tobin's Q (TQ), but only significant for ROE. In disaggregate, the result revealed that there is a significant positive relationship between S score with (ROE and TQ) and G score with TQ. Theoretically, sustainable finance and stakeholder engagement promote profitable growth in equity returns which enhance corporate performance. Policymakers, regulators, and governments should improve regulatory frameworks to ensure good ESG transparency in enhancing firm value.
\end{abstract}

Keywords: environmental, social and governance, Corporate Sustainability Reporting, FTSE4Good, Sustainable Finance, Financial Performance

\section{ARTICLE INFO}

Article History:

Received: 14 July 2021

Accepted: 04 November 2021

Available online: 01 December 2021

\footnotetext{
" Corresponding Author: Jasman Tuyon, Faculty of Business and Management, Universiti Teknologi MARA, Sabah Branch, Kota Kinabalu Campus, Locked Bag 71, 88997 Kota Kinabalu, Sabah, Malaysia; Email: jasma402@uitm.edu.my; Tel: +608-8325161.
} 


\section{INTRODUCTION}

Sustainable development goals (SDG) is a Nobel and comprehensive development model idealize by the World Commission on Environment and Development (WCED) where it defined it as "development that meets the needs of the present without compromising the ability of future generations to meet their own needs" (WCED, 1987, p. 41). The concept of 'needs' is to devise the vital necessities of poverty as the prime concern and to confront the needs of the present and future generations while considering environmental impact. Sustainable development is described through the triple bottom line that consists of three parameters built into the structural concept of economics, social and environmental aspects (Schoenmaker \& Schramade, 2019; Elkington, 1997). The environmental aspect, accentuates engaging into business practices without overexploiting the natural resources for future generations (Schoenmaker, 2017; Arowoshegbe \& Emmanuel, 2016). The social aspect refers to sustainable business practices aiming to fairly compensate labor, human capital and the community (Nikolaou et al., 2019; Schoenmaker, 2017; Arowoshegbe \& Emmanuel, 2016). The economic aspect, stresses on the effect of the organization's sustainable business practices towards the economic system (Elkington, 1997).

In line with the sustainability ideology, corporate sustainability practices which reflect as a commitment to the improvement of environmental (E), social (S), and governance (G) factors become prominently extensive as a means of assessing long-term value (Tamimi \& Sebastianelli, 2017). Stakeholders and investors are concerned about firm's ESG activities as it could affect firm profitability in the long term (Atan et al., 2017). According to Institute of Chartered Accountants in England and Wales (2015), the developments in environmental science and the drastic repercussions of the financial crisis have solidified the importance of sustainability in today's business and society. To support the sustainability agenda, sustainable corporate finance needs to be further developed to address the ESG risks in the operational and financial performances of corporations.

As can be seen in Figure 1, the global corporate sustainability reports database indicates a rising trend from 10345 (2016) to 12835 (2020). In Malaysia, firms' participation in sustainability practices has also been expanding from 65 (2016) to 109 (2020). Despite such positive trends, the 
statistics is still very low which is only $11.64 \%$ out of 936 listed firms in Bursa Malaysia as of 2020. The global growth of corporate sustainability practices in developing countries are rapidly growing and gaining momentum in the Association of Southeast Asian Nations (ASEAN) countries with regulations and laws grounded in integrating the elements of sustainability in corporate practices (Global Reporting Initiative, 2020). However, sustainable development finance practices remain neglected in theory, policy, and practice in Malaysian financial markets and firms due to the fact that the individuals, firms and market practices are guided by modern finance theories which are only concerned with wealth maximization (Mohammad \& Wassiuzzaman, 2021; Ismai et al., 2020; Schoenmaker, 2017; Stampe \& McCarron, 2015). Few empirical evidence has pointed out several gaps which will be addressed in this present research. First, several studies have been conducted globally with contradictory findings ranging from positive (Bhaskaran et al., 2021; Chouaibi \& Chouaibi, 2020; Albitar et al., 2019; Zhao et al., 2018; Aboud \& Diab, 2018) to negative (Bodhanwala \& Bodhanwala, 2021; Buallay et al., 2020) to mixed (Buallay, 2019; Garg, 2015) and even to insignificant (Buallay, 2021; Atan et al., 2017). In addition to those findings, evidence from emerging economies such as Malaysia have not been sufficiently explored which explains how the ideology still remains inconclusive. Previous researchers have been using content analysis methods in extracting sustainability information reported in annual reports and neglecting the use of ESG (aggregate indicator) and its individual dimension (disaggregate indicator) in their analysis (Morioka \& Monteiro de Carvalho, 2016).

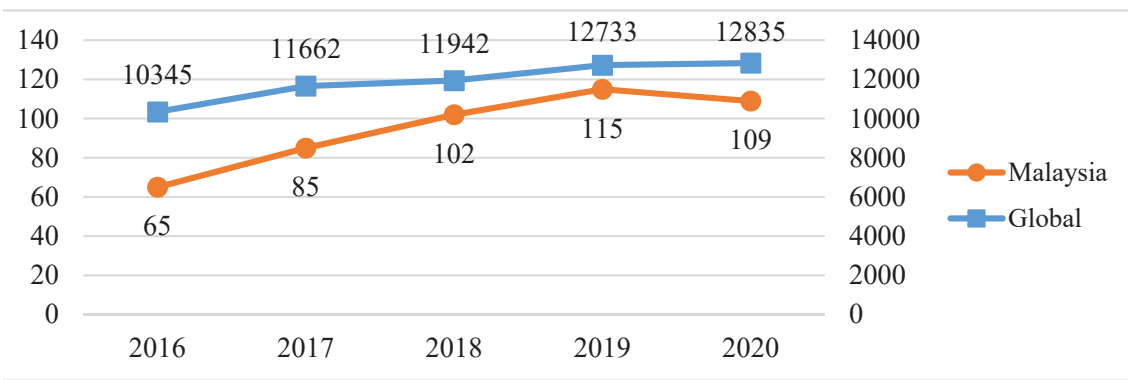

Figure 1: Sustainability Reports Trends: Global vs. Malaysia (2016-2020) Source: http://www.corporateregister.com/livecharts 
The gaps mentioned above are still relevant in the present corporate practices and need further investigation. In addressing the research gaps, this study aimed to provide a comprehensive theoretical and empirical analysis on the impact of sustainability practices on firm financial performance in the context of Malaysia using both aggregate and disaggregated ESG data. This research advanced the investigation of firm sustainability practices impacts in the following ways. The earlier evidence in the Malaysian context employed the content analysis method in measuring the sustainability practices variable. In recent research, the ESG score was used, but the individual dimensions (E, S and G) were ignored, and none of the studies in the Malaysian context used economic proxies. Empirically, this study incorporated all the sustainability proxies (ESG, E, S and G) eliminating the use of the content analysis method with a time frame up to 2019. The economic control variables (inflation, banking development and stock market development) which indicates a country's situation were also incorporated in this study. As a result, the outcome will have significant implications for shareholders, investors, and managers within the country. From a theoretical perspective, the incorporation of the sustainable finance theories explains the link between the three main components of sustainability (E, S and G) and firm performance which could not be theoretically explained by stakeholder theory alone which have been popularly used in the existing studies. Collectively, this study will contribute to the advancement of theory, policy and practices which would be valuable to academicians, practitioners and policymakers concerning the validity of the sustainable finance ideology.

\section{LITERATURE REVIEW}

\section{Theoretical Review of Corporate Sustainability}

\section{Stakeholder theory}

The Shareholders Theory was first argued by Freeman (1984) who was against the idea that firms should only focus on profit maximization. The Theory is in contrast with this idea as it explains that creating long term relationship with stakeholders will maximize firms' profits in the end. Friedman (1962) argued that maximizing profits is the main goals of a firm in striving for success. According to Freeman et al. (2010), maximizing profit will not create value for firms and should not be seen as a goal but 
an outcome instead. Both of them have opposing views on what a firm's goals should be, indicating that their perspectives are incompatible. Freeman (1984) further added that striving for maximizing stakeholders' wealth will eventually lead to shareholders maximization. Stakeholders refers to any individual or group that can be affected by the organization's goals such as investors, employees, customers, government, suppliers and other related parties who play a vital role in a firm (Arowoshegbe \& Emmanuel, 2016). Investment in sustainability requires more resources than investing for profit maximization to enable the needs to maximize a firm's value at least in a long term. The most influential stakeholders that can affect firms' operations are customers, employees, communities, suppliers and shareholders. Shareholders are considered as one of the stakeholders due to the similarity with investors who can be highly affected by the business operations. If resources are invested in a sustainable way through allocation of non-financial activities, it will it will create long term value for a firm. Investing in sustainability can reduce cash flow in a short run but in the long run, it will lead to cash hoarding and increase funds while minimizing risks. Freeman (1984) explained that taking into account the needs of stakeholders, will not only add value to stakeholders, but to firms as well.

\section{Sustainable finance theory}

The general perspective of sustainable finance is to incorporate the three main components of sustainability which are economics, environmental and social (EES) (Ziolo et al., 2018). However, most firms use ESG as firm sustainability disclosure measurement in corporate finance practices. In the Sustainable Finance Theory, ESG information is linked to firm valuation and performance through three channels. First, the cash-flow channel where sustainability practices promote firms to be more competitive which is positively related to profitability. Second, the idiosyncratic risk channel which suggests that better risk management will reduce firm risks. Third, the valuation channel which suggests that sustainable firms have a lower systematic risk and higher valuation (Giese et al., 2019). The evolution focuses from shareholder's value to stakeholders by incorporating the Triple Bottom Line (TBL) approach concerning the planet, profit and people. Investors nowadays are concerned about the risks involving the impact of ESG on firm performance which points out the needs of incorporating the elements in investment decisions (Weber et al., 2010). In the long run, the transparency of a firm's non-financial information is the crucial part of 
progressing towards sustainable development whereas traditional finance theories are too narrow to put the elements into decision making as long as it promotes better cash flow to achieve their main goals (Soppe, 2004). The financial sector plays a major role in transitioning towards sustainable economy. As investment firms, sustainable projects are more favourable to them in accelerating the transition. Sustainable finance helps in dealing with the uncertainties by evaluating risks affecting future cash flow of the firms in reducing cost during the production process (Schoenmaker, 2017). Financial institutions and investment firms avoid investing in particular sectors with negative impacts such as high carbon emissions, overuse of non-renewable resources, exploiting child labour and land degradation which consequently affects a firm's ability to obtain funds. As such, firms incorporate relevant sustainable policies in decision making aiming at a long-term approach in optimising the EES dimensions to prevent further losses associated with social and environmental impacts which eventually increase profitability (Soppe, 2004).

\section{Sustainable Reporting Policy and Practices in Malaysia}

Bursa Malaysia reporting guidelines - Sustainability disclosure became a listing requirement in Bursa Malaysia in 2006. At that time there was only a corporate social responsibility (CSR) framework established with four main areas, environment, community, marketplace and workplace (Bursa Malaysia, 2018). However, there was no constructive guideline on how this information should be disclosed raising questions to many firms and which lead to low quality and extent of non-financial information. Bursa Malaysia initiated its sustainability framework back in October 2015, in the hope to properly guide Malaysian public listed firms in committing and practicing sustainability (Bakar et al., 2019). The reporting guideline provided by Bursa Malaysia was prepared according to the Global Reporting Initiative (GRI) framework (Molla et al, 2019). In the Bursa Malaysia reporting guideline, sustainability is regarded as the EES. The main contents in the sustainability statement must be disclosed accordingly. First, the sustainability statement must be comparable, balanced and meaningfully reflect both the positive and negative aspects of a firm's sustainability performance. Second, the corporate governance framework should ensure timely and accurate disclosure. Third, basis of the scope must be disclosed. Fourth, sustainability matters disclosure is required to explain the opportunities and risks emerge from EES impacts. 
FTSE4Good Bursa Malaysia index components - Financial Times Stock Exchange (FTSE) index is an ethical series of stock market investment launched by the FTSE Group in 2001. It was designed to measure the ESG practices worldwide covering the developed and developing index, emerging index, United States (US), United Kingdom (UK), the European market, the Japan, Taiwan, Malaysia and North American stock market exchange to promote transparency with a clearly defined ESG criteria as a tool for market participants' assessment (FTSE Russell, 2020). In 2014, the FTSE Group along with Bursa Malaysia launched the ESG index which was the FTSE4Good Bursa Malaysia Index. FTSE4Good aims to help investors in making better ESG investments in promoting better transparency through the ESG practices while helping transition to a sustainable economy with a lower carbon usage (Bursa Malaysia, 2018). The FTSE4Good Malaysia Index constituents are drawn and screened based on the ESG criteria from top 200 firms in the FTSE Bursa Malaysia EMAS index which comprises of the FTSE Bursa Malaysia Top 100 Index and Small Cap Index. The new mandate emphasizes on the inclusion of the ESG criteria through practicing good governance, socially ethical and environmentally safe consistent with the GRI and Bursa Malaysia reporting guideline (Bursa Malaysia, 2020).

FTSE4Good ESG Model - The FTSE4Good ESG model is a tool for investors to derive better investment decision by managing risks in portfolio analysis. The ESG offers an opportunity to help in aiding a corporate manager understand non-financial information as stakeholders nowadays are concerned about how and where the firm invests in conducting their business (Albitar et al., 2019). Linking the ESG factors with firm performance, enables investors to persuade firms to be more transparent hence improving their sustainability practices (Aboud \& Diab, 2018). The FTSE4Good ESG Model uses theme exposure and level scores to assess multiple dimensions that allows firm to understand the ESG practices in multiple dimensions (FTSE Russell, 2020). It comprises with an overall rating split into three pillars and thematic exposure and also scores which is built into over 300 individual indicator assessments which can be applied based on a firm's issue in relation to the ESG. The FTSE4Good ESG scores helps in assessing the range and variance of portfolios and identify the amount of risk bearing by the firms with a comprehensive non-financial information. This allows investors to analyze and develop their own perspectives about risks and return relationship simultaneously incorporating sustainability measurement in their decision making (FTSE Russell, 2020; Albitar et al., 2019). 


\section{Empirical Studies}

\section{ESG and firm financial performance}

Academic scholars argue that sustainable practices should bring positive impacts to financial economic sustainability of firms. Economic sustainability performance reflects the long-term profitability and financial sustainability of firms as measured in terms of long-term operational effectiveness, efficiency, productivity, earnings, return on investment and market values (Rezaee, 2016). To consider a wider measure of financial performance, this research used the following different operational financial performance namely; accounting measure, finance measure and economic measure. Various studies have been performed over the last few years in examining the relationship between sustainability and firm financial performance but the results have often been inconclusive, contradictory and inconsistent (Mohammad \& Wassiuzzaman, 2021, Buallay et al., 2020; Ismai et al., 2020; Mohammad, 2020; Albitar et al., 2019; Atan et al., 2017; Aggarwal, 2013). Firm performance measurements are classified into three main categories namely, operational, financial and market performance (Buallay et al., 2021). Researchers from previous studies use multiple types of variables in measuring firm financial performance such as ROA, ROE, ROIC, Tobin Q, EPS, NPM and GPM presented in (Batae et al., 2021; Bodhanwala \& Bodhanwala, 2021; Chuoaibi \& Chuoaibi, 2021; Ruan \& Liu, 2021; López-Toro et al., 2021; Yilmaz, 2021; Rahi et al., 2021; Buallay, 2021; Bansal et al., 2021). Numerous studies have shown the association between sustainability and firm financial performance from various countries.

Some found a positive relationship between sustainability and financial performance (Ahmad et al., 2021; Bhaskaran et al., 2021; López-Toro et al., 2021; Yilmaz, 2021; Bansal et al., 2021; Rahman \& Alsayegh, 2021; Mohammad \& Wasiuzzaman, 2021; Qoyum et al., 2021; Chouaibi \& Chouaibi, 2020; Mohamad, 2020; Ismai et al., 2020; Albitar et al., 2019; Buallay, 2019; Zhao et al., 2018; Aboud \& Diab, 2018; Bodhanwala \& Bodhanwala, 2018). Buallay (2019) argued that environmental factors have a substantial impact on financial and market profitability of European Union banks. Ahmad et al. (2021) stated that the intrinsic value of a stock can be well predicted by having a good ESG performance as it reduces information asymmetry between investors and firms. López-Toro et al. (2021) argued that 
it is vital for firms to focus not only on ESG integration but also on public information related to sustainable actions as it has significant influence on a firm's market value. Yilmaz (2021) implied that sustainable firms with a lower leverage level would have better financial performance. Bansal et al. (2021) indicated that a firm's social investment in ESG activities attracts market participants such as investors that promote greater benefits to firm operational efficiency.

Several studies have shown that sustainability has a negative impact on firm performance (Bodhanwala \& Bodhanwala, 2021; Ruan \& Liu, 2021; Buallay et al., 2020). Bodhanwala \& Bodhanwala (2021) argued that the negative impact might be due to investors who value the ESG ratings less or that the costs of compliance exceed the benefits. ESG compliance requires major implementation costs, which could affect future cash flows and overall financial performance. Ruan \& Liu (2021) indicated that firms may evolve into a serious cost burden due to ESG investing and will inevitably lead to a certain decline in firm performance over time due to the low degree of protection by investors. Buallay et al. (2020) stated that, firms put themselves at a competitive disadvantage by allocating resources to support social programmes and initiatives, compared to those institutions that are less socially responsible.

The association between ESG and business performance has been found to be mixed in several studies. Buallay (2019) who analysed 1,462 listed firms derived from 80 different countries concluded that there is a positive relationship between ESG and firm performance in manufacturing sector and negative in banking sector. Garg (2015) studied the impact of sustainability on firm performance of Indian firms. The study found a positive relationship in long run and negative a short run. Shakil et al. (2019) conducted research related to the ESG and bank financial performance of emerging markets in Malaysia. It was found that, there is a mixed result where environmental and social aspects have a positive relationship with firm performance while governance was insignificant. Similarly, a few other studies have found mixed results in the global market (Rodríguez-Fernández et al., 2019; Gunarsih \& Ismawati, 2018; Sahut \& Pasquini-Descomps, 2015). 
Few other studies have found no relationship or insignificant between the ESG and firm performance (Buallay, 2021; Junius et al., 2020; Atan et al., 2017). A possible explanation for this could be due to missing data for some of the variables and misspecification of the study model (Buallay, 2019). Furthermore, the primary explanation for why the ESG has no impact on earnings from asset management is due to public perspective of sustainable development goals, in which they are viewed as non-value adding, new and undeveloped factors that will not affect purchasing decisions (Junius et al., 2020; Atan et al., 2017).

In the Malaysian research context, the evidence can be found in Rahman \& Alsayegh, (2021); Qoyum et al., (2021); Ahmad et al., (2021); Mohammad \& Wassiuzzaman, (2021); Ismai et al., (2020); Mohammad, (2020); Shakil et al., (2019) and Atan et al., (2017). The use of the aggregate ESG scores is widely used in Rahman \& Alsayegh, (2021); Mohammad \& Wasiuzzaman, (2021); Junius et al., (2020); Ismai et al., (2020) and Mohamad, (2020) and very few took into account the individual dimension of the ESG. Some of the studies used a content analysis method using dichotomous scores to calculate the index score as presented in Ahmad et al., (2021) and Kengkathran, (2019). Previous studies also analysed multiple Asian countries, including Malaysia, (Qoyum et al., 2021; Junius et al., 2020; Rahman \& Alsayegh, 2021). Various performance proxies were used, but most of the researchers use Tobin's Q (Qoyum et al., 2021; Ahmad et al., 2021; Atan et al., 2017; Mohamad, 2020; Mohammad \& Wasiuzzaman, 2021) and few other studies used either the ROA or the ROE Junius et al., 2020; Ismai et al., 2020; Kengkathran, 2019). Briefly, most of the studies done in Malaysia used the time frame up to 2018 with one or two performance proxies.

\section{Hypotheses Development}

In line with the presented gaps, theories and empirical evidence, the following hypotheses were developed for this study. The variables of interest were the sustainability practices (ESG, E, S and G) impact on firms' financial performance (ROA, ROE and TQ). In addition, selected firms and economic variables were controlled in the model to minimize the effects of these variables on firm performance and the validity of sustainability practices impact on firm performance. This is in line with the framework suggested 
by Alshehhi et al. (2018). The previous empirical evidence mostly used the Stakeholders Theory as a theoretical underpinning linking sustainability practices to firm performance. This research added the sustainable finance ideology as a complementary theory that links sustainable corporate finance practice implications to firm performance. The following hypotheses were examined to see how sustainability practices impact firms' financial performance.

Aggregate model:

H1a: The ESG score is positively related to firm financial performance

Disaggregate model:

H2a: The Environmental score is positively related to firm financial performance

H3a: The Social score is positively related to firm financial performance H4a: The Governance score is positively related to firm financial performance

\section{DATA AND METHODOLOGY}

\section{Sample of Sustainable Firm}

The sample of sustainable firm selection process was conducted based on a few criteria. First, 936 firms from various sectors that are publicly traded in Malaysia were chosen as of 2020. Second, firms that are currently practicing sustainability listed on the FTSE4Good Bursa Malaysia index components were selected. As of 2020, 73 firms listed in the FTSE4Good Bursa Malaysia Index were identified. However, due to the lack of ESG data in the database, several firms were eliminated from the sample, leaving only 36 firms belonging to various sectors in Malaysia such as, consumer products and services, energy, financial services, healthcare, industrial products and services, plantation, property, technology, telecommunication and media, construction, transportation and logistics and utilities is selected to be analysed in this study. Table 1 presents the list of all the 36 firms used in this study. The sample time frame of the analysis used was from 2015 to 2019, which is equivalent to 5 years of analysis, with a total of 180 observations. The years 2015 to 2019 were chosen since very few firms 
disclosed their ESG scores prior to that and some data could not be found in the database. It is worth noting that the dataset used in this study was unbalanced due to several entities in the dataset that did not have the same number of observations and had missing values. The panel data underwent several tests before panel regression analysis was conducted.

Table 1: FTSE4Good Bursa Malaysia Index Components

\begin{tabular}{clcl}
\hline No. & \multicolumn{1}{c}{ Index components } & No. & \multicolumn{1}{c}{ Index components } \\
\hline 1 & Airasia Group Bhd & 19 & MMC Corporation Bhd \\
2 & Berjaya Sports Toto Bhd & 20 & My E.G. Services Bhd \\
3 & Bumi Armada Bhd & 21 & Parkson Holdings Bhd \\
4 & Digi.Com Bhd & 22 & Petronas Dagangan Bhd \\
5 & FGV Holdings Bhd & 23 & Petronas Gas Bhd \\
6 & Fraser \& Neave Holdings Bhd & 24 & PPB Group Bhd \\
7 & Gamuda Bhd & 25 & Press Metal Aluminium Holdings \\
& & & Bhd \\
8 & Genting Bhd & 26 & Sapura Energy Bhd \\
9 & Genting Malaysia Bhd & 27 & Sime Darby Bhd \\
10 & Genting Plantations Bhd & 28 & SP Setia Bhd \\
11 & IHH Healthcare Bhd & 29 & Telekom Malaysia Bhd \\
12 & IJM Corporation Bhd & 30 & Tenaga Nasional Bhd \\
13 & IOI Properties Group Bhd & 31 & Top Glove Corporation Bhd \\
14 & Malaysia Airports Holdings Bhd & 32 & UEM Sunrise Berhad \\
15 & Malaysia Marine And Heavy & 33 & UMW Holdings Bhd \\
& Engineering Bhd & & \\
16 & Maxis Berhad & 34 & Westports Holdings Bhd \\
17 & Media Prima Bhd & 35 & YTL Corporation Bhd \\
18 & MISC Bhd & 36 & YTL Power International Bhd \\
\hline
\end{tabular}

Source: 30/10/2020 @ FTSE International Limited 2020. All Rights Reserved

\section{Variables Measurement}

Table 2 presents the variable measurements used in this study. The variables used in this study consisted of three dependent variables, four independent variables, four firm controlled variables and three economic controlled variables. The firm financial performance measures were ROA, ROE and TQ. ROA measured the financial health of the firms. ROE 
measured the real return of shareholders' investment capital. TQ measured the market performance of firms, which is useful in evaluating firms from an investor's perspective. All of the firms' financial performance measurements were collected from the Refinitiv Eikon database in line with previous studies (Rodríguez-Fernández et al., 2019; Shakil et al., 2019; Bodhanwala \& Bodhanwala, 2018).

The independent variables consisted of sustainability proxy which represented as the ESG score. The individual dimensions of sustainability (E, S and G) were employed as independent variables to measure the relationship with firms' financial performance. There are 10 categories in Refinitiv Eikon database which reformulated the three pillars (E, S and $\mathrm{G})$. The final ESG score based on the three pillars reflects the overall ESG performance of the firms. ESG score is the relative sum of category weights which differ per industry for $\mathrm{E}$ and $\mathrm{S}$ pillars. In $\mathrm{G}$ pillar, the weight remains constant of all the industries. Refinitiv Eikon scores each of the pillars with a grading scale from $\mathrm{D}$ - to $\mathrm{A}+$ where in percentage it ranges from 0 to 100 .

A review of 132 papers from top-tier journals concerning the impact of sustainability practices on corporate financial performance by Alshehhi et al. (2018) advised to control for firm variables. Previous researchers using firm characteristic were firm size, leverage, earning and liquidity to control for the effect of ESG and firm performance (Qureshi et al., 2019; Bodhanwala \& Bodhanwala, 2018; Zhao et al., 2018; Atan et al., 2017; Wang $\&$ Sarkis, 2017). In addition, Alshehhi et al. (2018) also advised to control for economic variables. Economics conditions has been established as one of the factors affecting firm performance in political, economic, social and technological (PEST) analysis (Sammut-Bonnici \& Galea, 2015). Following Qureshi et al. (2019)'s model, the economics variables were included in the empirical models to control for the effect of economic factors on firm performance. The economic variables included were; annual inflation rate, banking development, and stock market development. 
Table 2: Variables Measurement

\begin{tabular}{|c|c|c|}
\hline Variable Name & Abbreviation & Measurements descriptions \\
\hline \multicolumn{3}{|l|}{ Dependent Variables } \\
\hline Return on asset & ROA & Net Income divided by total asset \\
\hline Return on equity & ROE & $\begin{array}{l}\text { Net Income divided by total } \\
\text { equity }\end{array}$ \\
\hline Tobin's Q & TQ & $\begin{array}{l}\text { Market value of firm divided by } \\
\text { replacement value of assets }\end{array}$ \\
\hline \multicolumn{3}{|c|}{ Independent Variables (Sustainability) } \\
\hline Environmental & $E$ & Environmental score \\
\hline Social & $\mathrm{S}$ & Social score \\
\hline Governance & G & Governance score \\
\hline ESG & ESG & $\begin{array}{l}\text { Environmental, social and } \\
\text { governance score }\end{array}$ \\
\hline \multicolumn{3}{|l|}{ Firm Controlled Variables } \\
\hline Earnings per share & EPS & $\begin{array}{l}\text { Net income before extraordinary } \\
\text { items divided by average share } \\
\text { outstanding }\end{array}$ \\
\hline Liquidity & LIQ & $\begin{array}{l}\text { Total current assets divided by } \\
\text { total current liabilities }\end{array}$ \\
\hline Firm Size & SIZE & Natural logarithm of total assets \\
\hline Firm Leverage & LEV & $\begin{array}{l}\text { Total debt divided by } \\
\text { shareholder's equity }\end{array}$ \\
\hline \multicolumn{3}{|c|}{ Economics Controlled Variables } \\
\hline Inflation & INF & $\begin{array}{l}\text { Annual inflation (consumer price } \\
\text { rate) }\end{array}$ \\
\hline Banking Development & BKD & $\begin{array}{l}\text { Domestic credit to private sector } \\
\text { by banks divided by GDP }\end{array}$ \\
\hline Stock Market Development & SMD & $\begin{array}{l}\text { Stock traded (total value) divided } \\
\text { by GDP }\end{array}$ \\
\hline
\end{tabular}

\section{Empirical Models}

In accordance with the research hypotheses, the employed regression model used in this study was the Static Panel Data Regression Model. Panel data has the ability to control for heterogeneity and address the endogeneity problems, which contributed towards unbiased results. This empirical model is in line with the empirical model used by previous researchers (Giese et al. 2019). This study estimates two models. The first model intended to examine the corporate sustainability practices (ESG) to firms' financial performance (ROA, ROE and TQ) while controlling for firm factors (EPS, 
LIQ, SIZE, and LEV) and economic factors (INF, BKD and SMD). Three equation models were tested as follows:

$$
\begin{aligned}
R O A_{i t}= & \beta_{0}+\beta_{1} E S G_{i t}+\beta_{2} E P S_{i t}+\beta_{3} L I Q_{i t}+\beta_{4} S I Z E_{i t}+\beta_{5} L E V_{i t}+\beta_{6} I N F_{i t} \\
& +\beta_{7} B K D_{i t}+\beta_{8} S M D_{i t}+\varepsilon_{i t} \\
R O E_{i t}= & \beta_{0}+\beta_{1} E S G_{i t}+\beta_{2} E P S_{i t}+\beta_{3} L I Q_{i t}+\beta_{4} S I Z E_{i t}+\beta_{5} L E V_{i t}+\beta_{6} I N F_{i t} \\
& +\beta_{7} B K D_{i t}+\beta_{8} S M D_{i t}+\varepsilon_{i t} \\
T Q_{i t}= & \beta_{0}+\beta_{1} E S G_{i t}+\beta_{2} E P S_{i t}+\beta_{3} L I Q_{i t}+\beta_{4} S I Z E_{i t}+\beta_{5} L E V_{i t}+\beta_{6} I N F_{i t} \\
& +\beta_{7} B K D_{i t}+\beta_{8} S M D_{i t}+\varepsilon_{i t}
\end{aligned}
$$

In the second model, the model aims to assess the individual variable of ESG score which comprises of E, S and G, to firm financial performance (ROA, ROE and TQ) while controlling for similar firm factors and economic factors as mentioned on the aggregate analysis. Three regression equation will be tested in this model are as follows:

$$
\begin{aligned}
R O A_{i t}= & \beta_{0}+\beta_{1} E_{i t}+\beta_{2} S_{i t}+\beta_{3} G_{i t}+\beta_{4} E P S_{i t}+\beta_{5} L I Q_{i t}+\beta_{6} S I Z E_{i t}+\beta_{7} \\
& L E V_{i t}+\beta_{8} I N F_{i t}+\beta_{9} B K D_{i t}+\beta_{10} S M D_{i t}+\varepsilon_{i t} \\
R O E_{i t}= & \beta_{0}+\beta_{1} E_{i t}+\beta_{2} S_{i t}+\beta_{3} G_{i t}+\beta_{4} E P S_{i t}+\beta_{5} L I Q_{i t}+\beta_{6} S I Z E_{i t}+\beta_{7} \\
& L E V_{i t}+\beta_{8} I N F_{i t}+\beta_{9} B K D_{i t}+\beta_{10} S M D_{i t}+\varepsilon_{i t} \\
T Q_{i t}= & \beta_{0}+\beta_{1} E_{i t}+\beta_{2} S_{i t}+\beta_{3} G_{i t}+\beta_{4} E P S_{i t}+\beta_{5} L I Q_{i t}+\beta_{6} S I Z E_{i t}+\beta_{7} \\
& L E V_{i t}+\beta_{8} I N F_{i t}+\beta_{9} B K D_{i t}+\beta_{10} S M D_{i t}+\varepsilon_{i t}
\end{aligned}
$$

To further mitigate various sources of irregularities that could impact the performance of the empirical model, the robustness check was performed. Robust standard errors were used in order to account for irregularities, autocorrelation and heteroscedasticity of the structure in the panel dataset.

\section{Estimation Procedure}

Several tests were carried out to ensure that this study followed the Best Linear Unbiased Estimation (BLUE) rules. First, unit root test was conducted in order to determine if the panel data sets were stationary or 
not by using the Hadri test. Second, this study applied the VIF test to detect if there was a multicollinearity problem between the variables. Third, a modified Wald statistic for groupwise heteroskedasticity test was used to determine whether heteroscedasticity existed in this model. This happens when the error terms do not have a constant variance, which could affect the model. Three panel data regression models, namely the Ordinary Least Square (OLS) Model, the Fixed Effects (FE) Model, and the Random Effects (RE) Model, were evaluated for their suitability. To choose the most appropriate model for this study, two statistical tests were used; the Hausman test and Breusch Pagan Lagrange Multiplier. These tests will establish the model that is most appropriate for estimating panel data. Additionally, this study also applied the robust standard error to obtain more accurate results. As such, any sources of irregularities were be eliminated concerning autocorrelation, multicollinearity and heteroscedasticity problems that will affect model estimation. Previous researchers also used robust standard error to address potential problems with heteroskedasticity and autocorrelation (Qoyum et al., 2021; Buallay, 2021; Bansal et al., 2021).

\section{DATA ANALYSIS AND RESULT}

\section{Descriptive and Correlation Analysis}

As shown in Table 3, the descriptive analysis result of the ESG score in Malaysia showed that the mean of the ESG score was 42.66 percent which reflected that most of the firms did not provide good relative ESG information. This indicates that there is no firm that completely obtained an aggregate score of more than 70 percent suggesting a high level of transparency according to the Eikon database. In terms of the individual dimension of the ESG, the mean for social score was the highest with 46.56 percent followed by governance and environmental score among the firms. This indicates that firms in Malaysia encourage social aspects within their report that eventually improve firm performance. In terms of the performance measures, the mean average of the ROA had a positive value within the sample used in the analysis with 4.99. A similar positive pattern was also observed for firm financial performance measured by the ROE and the TQ with 16.13 and 1.57 respectively as shown in Table 3. 
Table 3: Descriptive Statistics

\begin{tabular}{lccccccc}
\hline & ROA & ROE & TQ & E & S & G & ESG \\
\hline Mean & 4.99 & 16.13 & 1.57 & 36.50 & 46.56 & 42.66 & 42.66 \\
Median & 3.74 & 7.28 & 0.87 & 39.68 & 49.28 & 42.30 & 46.37 \\
Maximum & 38.43 & 314.39 & 9.92 & 77.08 & 87.98 & 87.68 & 73.83 \\
Minimum & -35.87 & -58.40 & 0.17 & 0.00 & 0.00 & 0.00 & 0.00 \\
Std. Dev. & 7.52 & 45.79 & 1.75 & 22.52 & 21.03 & 21.58 & 17.78 \\
Skewness & 0.19 & 5.04 & 2.92 & -0.20 & -0.57 & -0.11 & -0.91 \\
Kurtosis & 10.31 & 30.00 & 12.12 & 1.91 & 2.72 & 2.35 & 3.27 \\
Jarque-Bera & 401.88 & 6230.08 & 880.07 & 10.08 & 10.24 & 3.58 & 25.15 \\
Probability & 0.00 & 0.00 & 0.00 & 0.01 & 0.01 & 0.17 & 0.00 \\
Sum & 897.35 & 2904.14 & 283.21 & 6569.48 & 8381.40 & 7678.03 & 7678.42 \\
Sum Sq. Dev. & 10126.35 & 375349.30 & 545.28 & 90800.42 & 79148.77 & 83368.99 & 56587.83 \\
Observations & 180 & 180 & 180 & 180 & 180 & 180 & 180 \\
\hline & EPS & LIQ & SIZE & LEV & INF & SMD & BKD \\
\hline Mean & 0.24 & 1.79 & 16.52 & 0.96 & 1.92 & 36.05 & 120.68 \\
Median & 0.17 & 1.57 & 17.00 & 0.67 & 2.09 & 36.99 & 120.84 \\
Maximum & 1.31 & 7.63 & 19.00 & 7.80 & 3.87 & 43.08 & 123.07 \\
Minimum & -0.59 & 0.30 & 13.00 & 0.00 & 0.66 & 29.78 & 117.18 \\
Std. Dev. & 0.32 & 1.04 & 1.16 & 1.01 & 1.15 & 4.58 & 1.99 \\
Skewness & 0.87 & 2.39 & -0.46 & 2.89 & 0.58 & 0.14 & -0.70 \\
Kurtosis & 4.05 & 11.62 & 3.19 & 16.01 & 2.13 & 1.90 & 2.39 \\
Jarque-Bera & 30.88 & 727.95 & 6.54 & 1520.76 & 15.67 & 9.63 & 17.29 \\
Probability & 0.00 & 0.00 & 0.04 & 0.00 & 0.00 & 0.01 & 0.00 \\
Sum & 43.69 & 323.06 & 2974.00 & 173.47 & 345.60 & 6488.21 & 21722.04 \\
Sum Sq. Dev. & 18.58 & 195.12 & 238.91 & 181.41 & 235.19 & 3752.53 & 708.40 \\
Observations & 180 & 180 & 180 & 180 & 180 & 180 & 180 \\
\hline & & & & & & & \\
\hline
\end{tabular}

The correlation matrix for both dependent and independent variables are presented in Table 4. In the correlation analysis, the degree of the relation between variables is as important as the direction of the variables. The goals of the correlation matrix analysis are to assess whether there is a potential sign of multicollinearity (Kowalski \& Napiorkowski, 2014). As can be seen in the correlation matrix in Table 4, there was a positive relationship between the ESG score and firm financial performance as measured by the ROA and the ROE. This suggests that the firms in Malaysia that are 
implementing sustainability practices have better financial performance. Contrarily, the correlation between the ESG and the TQ indicated a negative relationship. In terms of the sustainability individual measurement, the social and environmental scores were positively correlated with the ROA. However, the governance score was negatively correlated. There was a positive correlation between the individual dimension of sustainability (E, $\mathrm{S}$ and $\mathrm{G}$ ) and firm financial performance measured by the ROE. In contrast, all the disaggregate ESG showed a negative relationship with the TQ. As environmental, social and governance scores are part of the ESG indicator, there was a positive relationship with the overall ESG score.

Table 4: Correlation Analysis

\begin{tabular}{lcccccccccccccc}
\hline & ROA & ROE & TQ & E & S & G & ESG & EPS & LIQ & SIZE & LEV & INF & SMD & BKD \\
\hline ROA & 1.00 & & & & & & & & & & & & & \\
ROE & 0.74 & 1.00 & & & & & & & & & & & & \\
TQ & 0.68 & 0.65 & 1.00 & & & & & & & & & & & \\
E & 0.02 & 0.07 & -0.11 & 1.00 & & & & & & & & & & \\
S & 0.03 & 0.14 & -0.03 & 0.60 & 1.00 & & & & & & & & & \\
G & -0.05 & 0.10 & -0.08 & 0.38 & 0.56 & 1.00 & & & & & & & & \\
ESG & 0.01 & 0.15 & -0.06 & 0.81 & 0.89 & 0.75 & 1.00 & & & & & & & \\
EPS & 0.42 & 0.11 & 0.08 & 0.08 & 0.21 & -0.06 & 0.08 & 1.00 & & & & & & \\
LIQ & 0.04 & -0.16 & -0.09 & 0.13 & 0.03 & -0.02 & 0.04 & 0.27 & 1.00 & & & & & \\
SIZE & -0.25 & -0.16 & -0.48 & 0.27 & 0.25 & 0.07 & 0.23 & 0.18 & 0.12 & 1.00 & & & & \\
LEV & 0.16 & 0.56 & 0.19 & 0.16 & -0.01 & 0.08 & 0.11 & -0.29 & -0.28 & 0.17 & 1.00 & & & \\
INF & 0.06 & 0.04 & 0.01 & -0.11 & -0.11 & 0.07 & -0.07 & 0.03 & -0.05 & 0.00 & -0.05 & 1.00 & & \\
SMD & 0.04 & 0.02 & 0.00 & 0.00 & -0.01 & 0.09 & 0.03 & 0.01 & -0.04 & 0.00 & -0.07 & 0.74 & 1.00 & \\
BKD & 0.06 & 0.02 & 0.04 & -0.19 & -0.17 & -0.10 & -0.20 & 0.03 & 0.02 & -0.01 & 0.00 & -0.53 & -0.62 & 1.00 \\
\hline
\end{tabular}

\section{Diagnostic Check}

Before the panel regression analysis, the Hadri test was performed to test for the stationary of the data. The result of the unit root test is presented in Table 5. The result showed that all of the variables were statistically significant at the $5 \%$ level of significance which revealed that all of the variables were stationary. Therefore, this study considered the panel dataset as stationary. Multicollinearity test was done through the VIF test. As a rule of thumb, if the value of the VIF is greater than 5, it indicates that multicollinearity could exists in the regression model (Studenmund, 2014). As can be seen in Table 5, the VIF test demonstrated a lower number of VIF indicating that there was no severe multicollinearity problem between the variables in the model. 
Table 5: Stationary Test and Multicollinearity Test

\begin{tabular}{|c|c|c|c|c|c|c|c|c|}
\hline \multirow[t]{2}{*}{ Variable } & \multicolumn{2}{|c|}{ Hadri test } & \multicolumn{3}{|c|}{ Dataset 1 (Aggregate) } & \multicolumn{3}{|c|}{$\begin{array}{c}\text { Dataset } 2 \\
\text { (Disaggregate) }\end{array}$} \\
\hline & z-Statistic & Probability & Variable & VIF & 1/VIF & Variable & VIF & $1 / \mathrm{VIF}$ \\
\hline ROA & 55.01 & 0.00 & ESG & 1.17 & 0.85 & $E$ & 1.8 & 0.56 \\
\hline ROE & 51.98 & 0.00 & EPS & 1.21 & 0.83 & S & 2.41 & 0.41 \\
\hline TQ & 19.72 & 0.00 & LIQ & 1.16 & 0.86 & G & 1.64 & 0.61 \\
\hline$E$ & 54.07 & 0.00 & SIZE & 1.15 & 0.87 & EPS & 1.3 & 0.77 \\
\hline S & 56.88 & 0.00 & LEV & 1.25 & 0.80 & LIQ & 1.21 & 0.82 \\
\hline G & 52.47 & 0.00 & INF & 2.38 & 0.42 & SIZE & 1.2 & 0.83 \\
\hline ESG & 50.60 & 0.00 & SMD & 2.69 & 0.37 & LEV & 1.3 & 0.77 \\
\hline EPS & 55.43 & 0.00 & BKD & 1.79 & 0.56 & INF & 2.49 & 0.40 \\
\hline LIQ & 58.35 & 0.00 & $\begin{array}{l}\text { Mean } \\
\text { VIF }\end{array}$ & 1.6 & & SMD & 2.7 & 0.37 \\
\hline SIZE & 48.85 & 0.00 & & & & BKD & 1.9 & 0.53 \\
\hline LEV & 58.60 & 0.00 & & & & $\begin{array}{l}\text { Mean } \\
\text { VIF }\end{array}$ & 1.8 & \\
\hline INF & 62.22 & 0.00 & & & & & & \\
\hline SMD & 62.22 & 0.00 & & & & & & \\
\hline BKD & 62.22 & 0.00 & & & & & & \\
\hline
\end{tabular}

In order to detect if there was heteroscedasticity in the data, the Wald test was performed. Heteroscedasticity can create parameters of the estimation to be inefficient, hence it is important to test for it. Table 6 presents the Wald Test for the heteroscedasticity test. The results showed that the p-value was less than 0.05 at 0.000 . There was no heteroscedasticity problem in the model. In order to address this problem, the Robust Standard Error Estimator was employed.

Table 6: Heteroskedasticity Test

\begin{tabular}{|c|c|c|c|c|c|}
\hline Wald test & $x^{2}(36)$ & Prob $>x^{2}$ & Wald test & $x^{2}(36)$ & Prob $>x^{2}$ \\
\hline Aggregate model & & & Disaggregate model & & \\
\hline ROA & 396805 & 0.000 & ROA & 85510 & 0.000 \\
\hline ROE & 73222 & 0.000 & ROE & 55291.49 & 0.000 \\
\hline TQ & 89605 & 0.000 & TQ & 89605 & 0.000 \\
\hline
\end{tabular}




\section{Model Selection Test}

In order to find which regression model fitted the best with the data, the Hausman test was performed to select the appropriate model between random effects and fixed effects. Table 7 shows the Hausman test result for the dependent variables for both the aggregate and disaggregate model. Hypothesis testing revealed that the p-value was not significant at 5\% level. Following that, the Breusch-Pagan Lagrange Multiplier Test was used to determine whether the random effect or the OLS will be used. Table 7 shows the result of the Breusch-Pagan Lagrange Multiplier Test and as the p-value was larger than 0.05 , it indicated that the pooled OLS estimation was the most efficient regression method to be used in this dataset.

Table 7: Hausman Test and Breusch-Pagan Lagrange Multiplier Test

\begin{tabular}{|c|c|c|c|c|c|}
\hline \multirow{2}{*}{ Model } & \multicolumn{2}{|c|}{ Hausman test } & \multirow{2}{*}{ Model } & \multicolumn{2}{|c|}{ BPLM Test } \\
\hline & $x^{2}(5)$ & Prob $>x^{2}$ & & $x^{2}(01)$ & Prob $>x^{2}$ \\
\hline Aggregate model & & & Aggregate model & & \\
\hline ROA & 1.880 & 0.865 & ROA & 0.000 & 1.000 \\
\hline ROE & 2.520 & 0.772 & ROE & 0.000 & 1.000 \\
\hline TQ & 0.580 & 0.988 & $\mathrm{TQ}$ & 0.000 & 1.000 \\
\hline Disaggregate model & & & Disaggregate model & & \\
\hline ROA & 2.080 & 0.955 & ROA & 0.000 & 1.000 \\
\hline ROE & 5.980 & 0.542 & ROE & 0.000 & 1.000 \\
\hline TQ & 1.100 & 0.993 & $\mathrm{TQ}$ & 0.000 & 1.000 \\
\hline
\end{tabular}

\section{Empirical Analysis}

\section{The impact of ESG (aggregate) and firm financial performance}

Table 8 presents the results of the OLS regression analysis for equation 1, 2, and 3 between the ESG score and firm financial performance (ROA, ROE and TQ). The result revealed that the ESG score had an insignificant positive impact on firm financial performance (ROA and TQ) indicating that the alternative hypotheses should be rejected. These findings demonstrated that, despite firms disclosing their sustainable development practices, asset management had little impact on ROA. The reason for this might be attributed to the public's indication that sustainable development adds no value to businesses and has no bearing on their decision to purchase a product or service (Junius et al., 2020). Similarly, the significant result for 
the TQ might be due to the excessive cost in ESG activities resulting in lower market value as the stock price is primarily used as firm's rating in which the ESG score could make the firm less valuable (Buallay, 2021). These results are in line with several studies (Buallay, 2021; Junius et al., 2020, Aggarwal, 2013; Atan et al, 2017). However, the result revealed that the ESG had a significant positive relationship with the ROE. This suggests that sustainability has a beneficial impact on intangible assets like shareholder satisfaction, which has an impact on a firm's equity investment. The results are in line with previous studies presented in (Yilmaz, 2021; López-Toro et al., 2021; Buallay, 2019; Bodhanwala \& Bodhanwala, 2018). To further mitigate various sources of irregularities that could impact the empirical model performance, robustness checks were performed. The result can be seen in Table 8 which shows similar findings indicating that it does not change the original result.

Table 8: Pooled OLS Regression (Aggregate ESG)

\begin{tabular}{cllllll}
\hline Variables/ & \multicolumn{2}{c}{ ROA } & \multicolumn{2}{c}{ ROE } & \multicolumn{2}{c}{ TQ } \\
\hline Models & \multicolumn{1}{c}{ (OLS) } & $\begin{array}{c}\text { (OLS } \\
\text { Robust) }\end{array}$ & \multicolumn{1}{c}{ OLS } & $\begin{array}{c}\text { OLS } \\
\text { (Robust) }\end{array}$ & OLS & $\begin{array}{c}\text { OLS } \\
\text { (Robust) }\end{array}$ \\
\hline Constant & -32.251 & -32.251 & -216.065 & -216.065 & 6.724 & 6.724 \\
& $(-0.85)$ & $(-0.80)$ & $(-1.02)$ & $(-0.96)$ & $(0.73)$ & $(0.68)$ \\
ESG & 0.017 & 0.0170 & $0.399^{* * *}$ & $0.399^{* *}$ & 0.002 & 0.002 \\
& $(-0.69)$ & $(0.71)$ & $(2.75)$ & 2.34 & $(0.32)$ & $(0.27)$ \\
EPS & $13.783^{* * *}$ & $13.783^{* * *}$ & $51.850^{* * *}$ & $51.850^{* * *}$ & $1.572^{* * *}$ & $1.572^{* * *}$ \\
& $(-9.43)$ & $(6.59)$ & $(6.37)$ & 5.89 & $(4.41)$ & $(5.59)$ \\
LIQ & 0.369 & 0.369 & -0.426 & -0.426 & 0.006 & 0.006 \\
& $(-0.83)$ & $(1.24)$ & $(-0.17)$ & -0.25 & $(0.06)$ & $(0.06)$ \\
SIZE & $-2.874^{* * *}$ & $-2.874^{* * *}$ & $-15.059^{* * *}$ & $-15.059^{* * *}$ & $-0.906^{* * *}$ & $-0.906^{* * *}$ \\
& $(-7.21)$ & $(-4.92)$ & $(-6.79)$ & -4.88 & $(-9.31)$ & $(-5.62)$ \\
LEV & $3.170^{* * *}$ & $3.17^{* * *}$ & $32.658^{* * *}$ & $32.658^{* * *}$ & $0.654^{* * *}$ & $0.654^{* * *}$ \\
& -6.66 & $(4.92)$ & $(12.32)$ & 5.11 & $(5.63)$ & $(4.05)$ \\
INF & 0.549 & 0.549 & $3.528^{* *}$ & 3.528 & 0.030 & 0.030 \\
& $(0.95)$ & $(1.01)$ & $(1.10)$ & 1.05 & $(0.21)$ & $(0.20)$ \\
SMD & 0.157 & 0.157 & 0.858 & 0.858 & 0.021 & 0.021 \\
& $(1.02)$ & $(1.13)$ & $(1.00)$ & 0.98 & $(0.56)$ & $(0.55)$ \\
BKD & $0.581^{* *}$ & 0.581 & $3.173^{* *}$ & 3.173 & 0.065 & 0.065 \\
& $(2.02)$ & $(1.95)$ & $(1.98)$ & 1.67 & $(0.93)$ & $(0.85)$ \\
\hline
\end{tabular}




\begin{tabular}{llll}
\hline R-Squared & 0.444 & 0.535 & 0.385 \\
Prob & & 0.000 & 0.000 \\
(F-statistic) & 0.000 & 180 & 180 \\
Observation & 180 & 180 & \\
\hline
\end{tabular}

Table 9: Pooled OLS Regression (Disaggregate ESG)

\begin{tabular}{|c|c|c|c|c|c|c|}
\hline \multirow{2}{*}{$\begin{array}{c}\text { Variables/ } \\
\text { Models }\end{array}$} & \multicolumn{2}{|c|}{ ROA } & \multicolumn{2}{|c|}{ ROE } & \multicolumn{2}{|c|}{$\mathrm{TQ}$} \\
\hline & (OLS) & $\begin{array}{c}\text { (OLS } \\
\text { Robust) }\end{array}$ & OLS & $\begin{array}{c}\text { OLS } \\
\text { (Robust) }\end{array}$ & OLS & $\begin{array}{c}\text { OLS } \\
\text { (Robust) }\end{array}$ \\
\hline \multirow[t]{2}{*}{ Constant } & -43.811 & -43.811 & -270.494 & -270.494 & 2.725 & 2.725 \\
\hline & $(-1.13)$ & $(-1.03)$ & $(-1.29)$ & $(-1.04)$ & $(0.29)$ & $(0.26)$ \\
\hline \multirow[t]{2}{*}{$E$} & 0.018 & 0.018 & -0.207 & -0.207 & -0.006 & -0.006 \\
\hline & $(0.71)$ & $(0.86)$ & $(-1.50)$ & $(-1.64)$ & $(-1.12)$ & $(-1.20)$ \\
\hline \multirow[t]{2}{*}{$S$} & 0.032 & 0.032 & $0.667^{* * *}$ & $0.667^{* *}$ & $0.02^{* \star *}$ & $0.02^{\star *}$ \\
\hline & $(1.02)$ & $(0.76)$ & $(3.87)$ & $(2.25)$ & $(2.76)$ & $(2.21)$ \\
\hline \multirow[t]{2}{*}{ G } & -0.032 & -0.032 & -0.104 & -0.104 & $-0.013^{\star *}$ & -0.013 \\
\hline & $(-1.27)$ & $(-1.19)$ & $(-0.76)$ & $(-0.63)$ & $(-2.21)$ & $(-1.95)$ \\
\hline \multirow[t]{2}{*}{ EPS } & $13.252^{\star * *}$ & $13.252^{\star * *}$ & $45.777^{\star * \star}$ & $45.777^{\star \star \star}$ & $1.299^{\star * *}$ & $1.299^{\star * *}$ \\
\hline & $(8.74)$ & $(5.84)$ & $(5.54)$ & $(5.56)$ & $(3.57)$ & $(4.41)$ \\
\hline \multirow[t]{2}{*}{ LIQ } & 0.370 & 0.370 & 1.135 & 1.135 & 0.052 & 0.052 \\
\hline & $(0.82)$ & $(1.25)$ & $(0.46)$ & $(0.63)$ & $(0.49)$ & $(0.53)$ \\
\hline \multirow[t]{2}{*}{ SIZE } & $-2.988^{* * *}$ & $-2.988^{* \star *}$ & $-15.620^{* * *}$ & $-15.620^{\star * *}$ & $-0.941^{* \star *}$ & $-0.941^{* * *}$ \\
\hline & $(-7.36)$ & $(-4.84)$ & $(-7.06)$ & $(-4.87)$ & $(-9.66)$ & $(-5.70)$ \\
\hline \multirow[t]{2}{*}{ LEV } & $3.192^{\star \star \star}$ & $3.192^{* * *}$ & $34.622^{\star \star \star}$ & $34.622^{\star \star \star}$ & $0.71^{* * *}$ & $0.71^{* * *}$ \\
\hline & (6.58) & $(4.70)$ & (13.09) & $(5.04)$ & $(6.10)$ & $(4.02)$ \\
\hline \multirow[t]{2}{*}{ INF } & 0.746 & 0.746 & 4.147 & 4.147 & 0.088 & 0.088 \\
\hline & $(1.27)$ & (1.27) & (1.29) & $(1.23)$ & $(0.62)$ & $(0.58)$ \\
\hline \multirow[t]{2}{*}{ SMD } & 0.167 & 0.167 & 1.034 & 1.034 & 0.027 & 0.027 \\
\hline & (1.09) & (1.19) & $(1.24)$ & (1.19) & $(0.76)$ & $(0.74)$ \\
\hline \multirow[t]{2}{*}{ BKD } & $0.687^{\star * *}$ & $0.687^{* * *}$ & $3.595^{\star *}$ & 3.595 & 0.099 & 0.099 \\
\hline & $(2.32)$ & $(2.10)$ & $(2.23)$ & (1.64) & (1.39) & (1.18) \\
\hline R-Squared & 0.452 & & 0.561 & & 0.414 & \\
\hline Prob (F-statistic) & 0.000 & & 0.000 & & 0.000 & \\
\hline Observation & 180 & & 180 & & 180 & \\
\hline
\end{tabular}




\section{The impact of $E, S$ and $G$ (disaggregate) and firm financial performance}

Table 9 presents the results of the OLS regression analysis for equation 4, 5 and 6 used to examine the relationship between environmental, social and governance and firm financial performance (ROA, ROE and TQ). The result revealed that there is a high explanatory power and high statistical significance as the p-value of the F-statistic was less than the 5 percent significance level. First, based on equation 4, there was an insignificant positive relationship between individual dimension ( $\mathrm{E}$ and $\mathrm{S}$ ) with the ROA. This result is in line with previous studies (Rodríguez-Fernández et al., 2019; Buallay, 2019). Similarly, there was an insignificant negative relationship between the $\mathrm{G}$ score and the ROA. Second, equation 5 was tested and resulted in an insignificant negative relationship for the $\mathrm{E}$ and $\mathrm{G}$ score with the ROE in line with previous studies such as Buallay (2019). Contrarily, the result for the $\mathrm{S}$ score indicated a significant positive relationship with the ROE. Equation 6 tested the relationship between individual sustainability dimensions (E, S, and $\mathrm{G}$ ) and firm financial performance (TQ). The results revealed that there was a significant negative relationship between the G score and the TQ in line with Bodhanwala \& Bodhanwala (2021). Shareholders and investors may believe that investing time and money in ESG activities does not directly improve a firm's revenues or profits, and that it is distracting management from its core business, which explains the negative relationship (Buallay, 2021; Ruan \& Liu, 2021; Bodhanwala \& Bodhanwala, 2021).

In addition, the effect was significant for social score and the TQ indicating a positive relationship. The result matched those observed in earlier studies (Chouaibi \& Chouaibi, 2020; Yilmaz, 2021). This indicates that, a commitment towards socially responsible practices and a greater use of ethical behavior appears to be crucially important for improved financial performance (Chouaibi \& Chouaibi, 2020; Yilmaz, 2021). In terms of the environmental score, there was an insignificant negative relationship between the E score and the TQ similar to previous studies (Buallay, 2021; Ahmad et al., 2021). The robustness test revealed that the E score result against ROE had changed indicating a positive relationship but the result still remained insignificant. Moreover, the result for the G score and the TQ resulted in a statistically insignificant negative relationship. 


\section{CONCLUSION}

To recap, this study examined the relationships between the ESG and its individual dimensions (E, S and $\mathrm{G}$ ) and firm financial performances (ROA, ROE and TQ) among a sample of 36 sustainable practicing firms in Malaysia from 2015 to 2019 . At the aggregate level, the results indicated a positive relationship between sustainability (ESG) and firm financial performance measures (ROA, ROE and TQ) but only significant for the ROE. For the disaggregate level of sustainability proxies (E, S and $\mathrm{G})$, the result revealed that there was a significant positive relationship between the $\mathrm{S}$ score with (ROE and TQ) and the G score with the TQ. This indicates that the firms' investment in sustainability had led to an increase of return on equity of shareholders. As there was a positive connection the ESG and firm performance, the Sustainable Finance Theory is valid. It means the firms' decision to incorporate relevant sustainable policies (E, S and $G$ ) for longterm approach dimensions helps to improve cash flow and reduce external risks that can lead to further loss associated with social and environmental impacts. Since there was a positive effect between the $\mathrm{S}$ score and firm performance, the Stakeholder's Theory is valid in explaining how creating long term relationship with stakeholders will maximize firm's profits in the long term.

Our findings revealed that sustainability practices in Malaysia are expanding but still lacking in terms of transparency especially on the environmental and governance aspects. This might be due to the fact that investors believe that time and money invested on governance and environmental activities do not directly improve a firm's revenues or profits. As such, firms do not consider governance and environmental investment as it could inevitably result in a decline in firm performance over time as a result of investors' lack of protection except for social activities. Over the past decades, firms are mostly allocating their funds for social activities and it has been widely practiced by both private and public firms in Malaysia through CSR. Likewise, policymakers, regulators and the government should pay more attention to issues impacting the ESG activities in firms by enhancing regulatory frameworks to ensure good transparency (Rahi et al., 2021; López-Toro et al., 2021). Firms should implement better sustainable development strategies in their business to ensure better access to capital while reducing risks for long term valuation. 
This paper provides useful insights to limited exploration through the inclusion of the ESG indicators at the firm level. Firm equity investment can be seen as the root that will assist in achieving sustainable development goals (SDG) through resources allocation and funding. The limitation of this study is related to the sample of the study. This study used a small number of sample so the results have to be interpreted in limited way and not generalized to all the public listed firms in Malaysia. This is due to the unavailability of the ESG score data for some firms which reduces the sample size. Further studies may consider expanding the sample size and time frame in order to obtained more significant, reliable and consistent results. It is also recommended to compare the performance between countries or segregating the dataset in accordance to their own respective industries. This study focused mainly on aggregate and disaggregate ESG data in which there are various indicators under the ESG pillars such as emission, innovation, resource use, CSR strategy, management, shareholders, community, human rights, product responsibility and workforce. The inclusion of this individual items could contribute to reveal more specific information about the factors that could affect the ESG within each item.

\section{REFERENCES}

Aboud, A., \& Diab, A. (2018). The impact of social, environmental and corporate governance disclosures on firm value: Evidence from Egypt. Journal of Accounting in Emerging Economies, 8(4), 442-458. https:// doi.org/10.1108/JAEE-08-2017-0079.

Aggarwal, P. (2013). Impact of sustainability performance of company on its financial performance: A study of listed Indian companies. Global Journal of Management and Business Research, 13(11), 60-70. https:// journalofbusiness.org/index.php/GJMBR/article/view/1150.

Ahmad, R. A. R., Ayob, A. A., Zainon, S., \& Probohudono, A. N. (2021). The influence of environmental, social and governance reporting on firm value: Malaysian evidence. International Journal of Academic Research in Business and Social Sciences, 11(9), 1058-1080. http:// dx.doi.org/10.6007/IJARBSS/v11-i9/10877. 
Albitar, K., Hussainey, K., Kolade, N., \& Gerged, A.M. (2019). ESG disclosure and firm performance before and after IR: The moderating role of governance mechanisms. International Journal of Accounting and Information Management, 28(2), 1-21. https://doi.org/10.1108/ IJAIM-09-2019-0108.

Alshehhi, A., Nobanee, H., \& Khare, N. (2018). The impact of sustainability practices on corporate financial performance: Literature trends and future research potential. Sustainability, 10(2), 494. https://doi. org/10.3390/su10020494.

Arowoshegbe, A.O., \& Emmanuel, U. (2016). Sustainability and triple bottom line: an overview of two interrelated concepts. Igbinedion University Journal of Accounting, 2, 88-125. https://www.iuokada.edu. ng/journals/9F2F7F6B56B433D.pdf.

Atan, R., Alam, M.M., Said, J., \& Zamri, M. (2017). The impacts of environmental, social and governance factors on firm performance: Panel study on Malaysian companies. Management of Environmental Quality: An International Journal, 29(2), 182-194. https://doi. org/10.1108/MEQ-03-2017-0033.

Bakar, A. B. S. A., Ghazali, N.A. B. M., \& Ahmad, M. B. (2019). Sustainability reporting in Malaysia-The extent and quality. International Journal of Academic Research in Business and Social Sciences, 9(5), 816-835. http://dx.doi.org/10.6007/JJARBSS/v9-i5/6009.

Bansal, M., Samad, T.A., \& Bashir, H.A. (2021). The sustainability reporting-firm performance nexus: evidence from a threshold model. Journal of Global Responsibility. https://doi.org/10.1108/JGR-052021-0049.

Batae, O.M., Dragomir, V.D., \& Feleaga, L. (2021). The relationship between environmental, social and financial performance in the banking sector: A European study. Journal of Cleaner Production. 290, 1-21. https://doi.org/10.1016/j.jclepro.2021.125791. 
Bhaskaran, R.K., Sujit, K.S., \& Mongia, S. (2021). Linkage between performance and sustainability initiatives in banking sector: An empirical examination. International Journal of Productivity and Performance Management. https://doi.org/10.1108/IJPPM-07-2020-0385.

Bodhanwala, S., \& Bodhanwala, R. (2018). Does corporate sustainability impact firm profitability? Evidence from India. Management Decision, 56(8), 1734-1747. https://doi.org/10.1108/MD-04-2017-0381.

Bodhanwala, S., Bodhanwala, R. (2021). Exploring relationship between sustainability and firm performance in travel and tourism industry: A global evidence. Social Responsibility Journal. https://doi.org/10.1108/ SRJ-09-2020-0360.

Buallay, A. (2019). Is sustainability reporting (ESG) associated with performance? Evidence from the European banking sector. Management of Environmental Quality, 30(1), 98-115. https://doi.org/10.1108/MEQ12-2017-0149.

Buallay, A. (2019). Sustainability reporting and firm's performance: Comparative study between manufacturing and banking sectors. International Journal of Productivity and Performance Management, 69(3), 431-445. https://doi.org/10.1108/IJPPM-10-2018-0371.

Buallay, A. (2021). Sustainability reporting and agriculture industries' performance: worldwide evidence. Journal of Agribusiness in Developing and Emerging Economies. https://doi.org/10.1108/ JADEE-10-2020-0247.

Buallay, A., Fadel, S.M., Alajmi, J., \& Saudagaran, S. (2020). Sustainability reporting and bank performance after financial crisis: Evidence from developed and developing countries. International Business Journal, 31(4), 747-770. https://doi.org/10.1108/CR-04-2019-0040.

Bursa Malaysia. (2018). Sustainability reporting guide. Retrieved from https://bursasustain.bursamalaysia.com/droplet-details/resources/ sustainability-reporting-guide-2nd-edition. 
Bursa Malaysia. (2020). FTSE4Good Bursa Malaysia Index. Retrieved June 15, 2020, from https://bursasustain.bursamalaysia.com/droplet-details/ resources/ftse4good-bursa-malaysia-index.

Chouaibi, S., \& Chouaibi, J. (2020). ESG and corporate financial performance: the mediating role of green innovation: UK common law versus Germany civil law. EuroMed Journal of Business. https://doi. org/10.1108/EMJB-09-2020-0101.

Elkington, J. (1997). Cannibals with forks: the triple bottom line of the $21^{\text {st }}$ century. Oxford: Capstone publishing limited.

Freeman, R. E. (1984). Strategic management: A Stakeholder Approach. $1^{\text {st }}$ edition. Boston: Pitman

Freeman, R.E., Harrison, J., Hicks, A., Parmar, B., \& de Colle, S. (2010). Stakeholder theory: The state of the art. $1^{\text {st }}$ edition. New York: Cambridge University Press. http://dx.doi.org/10.1080/19416520.20 10.495581

Friedman, M. (1962). Capitalism and Freedom. $1^{\text {st }}$ edition. Chicago: University of Chicago Press.

FTSE Russell. (2020). About FTSE Russell. Retrieved June, 15, 2020, from https://www.ftserussell.com/about-us.

Garg, P. (2015). Impact of sustainability reporting on firm performance of companies in India. International Journal of Marketing and Business Communication, 4(3), 39-45. http://dx.doi.org/10.21863/ ijmbc/2015.4.3.018.

Giese, G., Lee, L. E., Melas, D., Nagy, Z., \& Nishikawa, L. (2019). Foundations of ESG investing: how ESG affects equity valuation, risk, and performance. The Journal of Portfolio Management, 45(5), 69-83. http://dx.doi.org/10.3905/jpm.2019.45.5.069.

Global Reporting Initiative. (2020). GRI's contribution to sustainable development. Retrieved from https://www.globalreporting.org/ 
resourcelibrary/GRI $\% 27 \mathrm{~s} \% 20$ Contribution $\% 20$ to $\% 20$ Sustainable $\% 20$ Development\%202016-2020\%20(2).pdf.

Gunarsih, T., \& Ismawati, Y. (2018). Sustainability report and firm performance: Study in mining and metal and food processing industry Indonesia stock exchange 2014-2017. Journal of Governance and Integrity, 2(1), 9-26. http://dx.doi.org/10.15282/jgi.2.1.2018.5533

Institute of Chartered Accountants in England and Wales. (2015). Environmental issues and UK annual reporting. Retrieved from https:// www.icaew.com/-/media/corporate/files/technical/sustainability/ tecpln12453-eiafr-annual-report-2nd-edition-final.ashx?la=en

Ismai, N., Md Isa, M.A., Abd Rahman, N.H., \& Mazlan, N.F. (2020). Sustainability performance using environmental, social and governance (ESG) scores: Evidence from public listed companies in Malaysia. International Journal of Accounting, Finance and Business, 5(30), 183-194. http://www.ijafb.com/PDF/IJAFB-2020-30-12-15.pdf

Junius, D., Adisurjo, A., Rijanto, Y.A., \& Adelina, Y.E. (2020). The impact of ESG performance to firm performance and market value. Jurnal Aplikasi Akuntasi, 5(1), 21-41. http://dx.doi.org/10.29303/jaa.v5i1.84

Kengkathran, S. (2019). Environmental, social and governance (ESG) disclosure and its impact on financial performance of Top 100 companies in Malaysia and Australia. International Journal of Engineering and Advanced Technology, 9(1), 3579-3584. http://dx.doi. org/10.35940\%2Fijeat.A2691.109119.

Kowalski, A.M., \& Napiorkowski, T.M. (2014). Statistical analysis of quantitative data. Poland: Warsaw School of Economics. https://www. researchgate.net/publication/312490489_Statistical_Analysis_of_ Quantitative_Data.

López-Toro, A.A., Sánchez-Teba, E.M., Benítez-Márquez, M.D., \& Rodríguez-Fernández, M. (2021). Influence of ESGC indicators on financial performance of listed pharmaceutical companies. International Journal of Environmental Research and Public Health, 18, 4556. https:// doi.org/10.3390/ijerph18094556 
Mohamad, N.E.A.B. (2020). Do environmental, social and governance practices (ESG) signify firm value? Evidence from FTSE4Good Bursa Malaysia (F4GBM). Global Business and Management Research, 12(4), 365-376. http://gbmrjournal.com/pdf/v12n4/V12N4-33.pdf.

Mohammad, W.M.W.M., \& Wasiuzzaman, S. (2021). Environmental, social and governance (ESG) disclosure, competitive advantage and performance of firms in Malaysia. Cleaner Environment System, 2, 2666-7894. https://doi.org/10.1016/j.cesys.2021.100015.

Molla, M.S., Ibrahim, Y., \& Ishak, Z. (2019). Corporate sustainability practices: A review on the measurements, relevant problems and a proposition. Global Journal of Management and Business Research, 19(1), 1-8. https://www.journalofbusiness.org/index.php/GJMBR/ article/view/2666.

Morioka, S.N., \& Monteiro de Carvalho, M. (2016). A systematic literature review towards a conceptual framework for integrating sustainability performance into business. Journal of Cleaner Production, 136, 134146. https://doi.org/10.1016/j.jclepro.2016.01.104.

Nikolaou, I.E., Tsalis, T.A., \& Evangelinos, K.I. (2019). A framework to measure corporate sustainability performance: a strong sustainabilitybased view of firm. Sustainable Production and Consumption, 18, 1-18. https://doi.org/10.1016/j.spc.2018.10.004.

Qoyum, A., Sakti, M.R.P., Thaker, H.M.T., \& Alhashfi, R.U. (2021). Does the Islamic label indicate good environmental, social, governance (ESG) performance? Evidence from sharia-compliant firms in Indonesia and Malaysia. Borsa Instanbul Review. https://doi.org/10.1016/j. bir.2021.06.001.

Qureshi, M. A., Kirkerud, S., Theresa, K., \& Ahsan, T. (2019). The impact of sustainability (environmental, social, and governance) disclosure and board diversity on firm value: The moderating role of industry sensitivity. Business Strategy and the Environment, 29(3), 1199-1214. https://doi.org/10.1002/bse.2427. 
Rahi, A.F., Akter, R. \& Johansson, J. (2021). Do sustainability practices influence financial performance? Evidence from the Nordic financial industry. Accounting Research Journal. https://doi.org/10.1108/ARJ12-2020-0373.

Rahman, R.A., \& Alsayegh, M.F. (2021). Determinants of corporate environmental, social and governance (ESG) reporting among Asian firms. Journal of Risk and Financial Management, 14(4), 167. https:// doi.org/10.3390/jrfm14040167.

Rezaee, Z. (2016). Business sustainability research: A theoretical and integrated perspective. Journal of Accounting Literature, 36, 48-64. https://doi.org/10.1016/j.acclit.2016.05.003.

Rodríguez-Fernández, M., Sánchez-Teba, E.M., López-Toro, A.A., \& Borrego-Domínguez, S. (2019). Influence of ESGC indicators on financial performance of listed travel and leisure companies. Sustainability, 11, 1-20. https://doi.org/10.3390/su11195529.

Ruan, L., \& Liu, H. (2021). Environmental, social, governance activities and firm performance: Evidence from China. Sustainability, 13, 767. https://doi.org/10.3390/su13020767.

Sahut, J., \& Pasquini-Descomps, H. (2015). ESG impact on market performance of firms: International evidence. Management International, 19, 40-63. https://doi.org/10.7202/1030386ar.

Sammut-Bonnici, T., \& Galea, D. (2015). PEST analysis. Wiley Encyclopedia of Management, 12, 1-7. http://dx.doi.org/10.1002/9781118785317. weom120113.

Schoenmaker, D. (2017). Investing for the common good: a sustainable finance framework. Bruegel Essay and Lecture Series. https://bruegel. org/wp-content/uploads/2017/07/From-traditional-to-sustainablefinance_ONLINE.pdf.

Schoenmaker, D., \& Schramade, W. (2019). Principles of sustainable finance. Oxford: Oxford university press. https://www.researchgate. net/publication/330359025_Principles_of_Sustainable_Finance. 
Shakil, M.H., Mahmood, N., Tasnia, M., \& Munim, Z.H. (2019). Do environmental, social and governance performance affect the financial performance of banks? A cross-country study of emerging market banks. Management of Environmental Quality, 30(6), 1331-1344. https://doi. org/10.1108/MEQ-08-2018-0155.

Soppe, A. (2004). Sustainable corporate finance. Journal of Business Ethics, 53(1-2), 213-224. https://www.jstor.org/stable/25123294.

Stampe, J., \& McCarron, B. (2015). Sustainable Finance in Singapore, Indonesia and Malaysia: A review of financiers' ESG practices, disclosure standards and regulations. World Wildlife Fund for Nature: Gland, Switzerland. https://d2ouvy59p0dg6k.cloudfront.net/downloads/wwf_frc_forest_risk_ commodities_report_2015_online_1.pdf.

Studenmund, A.H. (2014). Using econometrics a practical guide (6th edition). United Kingdom: Pearson Education Limited.

Tamimi, N., \& Sebastianelli, R. (2017). Transparency among S\&P 500 companies: an analysis of ESG disclosure scores. Management Decision, 55(8), 1660-1680. https://doi.org/10.1108/MD-01-2017-0018.

Wang, Z., \& Sarkis, J. (2017). Corporate social responsibility governance, outcomes, and financial performance. Journal of Cleaner Production, 162, 1607-1616. https://doi.org/10.1016/j.jclepro.2017.06.142.

WCED, S.W.S. (1987). World commission on environment and development. Our common future. Oxford: Oxford university press. https://sustainabledevelopment.un.org/content/documents/5987ourcommon-future.pdf.

Weber, O., Scholz, R.W., \& Michalik, G. (2010). Incorporating sustainability criteria into credit risk management. Business Strategy and the Environment, 19(1), 39-50. https://doi.org/10.1002/bse.636.

Yilmaz, I. (2021). Sustainability and financial performance relationship: International evidence. World Journal of Entrepreneurship, Management and Sustainable Development, 17(3), 537-549. https://doi.org/10.1108/ WJEMSD-10-2020-0133. 
Zhao, C., Guo, Y., Yuan, J., Wu, M., Li, D., Zhou, Y., \& Kang, J. (2018). ESG and corporate financial performance: Empirical evidence from China's listed power generation companies. Sustainability, 10(8), 2607. https://doi.org/10.3390/su10082607.

Ziolo, M., Ben Ghoul, M.B., \& Aydin, H.I. (2018). Financial stability vs sustainable development and its financing. Sustainability, 11(15), 88104. http://dx.doi.org/10.4018/978-1-5225-4026-7.ch005. 
